\title{
Servants of a 'sinking titanic' or actors of change? Contested identities of social workers in Sweden
}

\author{
Jessica H. Jönsson
}

To cite this article: Jessica H. Jönsson (2018): Servants of a 'sinking titanic' or actors of change? Contested identities of social workers in Sweden, European Journal of Social Work, DOI: 10.1080/13691457.2018.1529659

To link to this article: https://doi.org/10.1080/13691457.2018.1529659

(c) 2018 The Author(s). Published by Informa
UK Limited, trading as Taylor \& Francis
Group

Submit your article to this journal $₫$

\section{山ll Article views: 3}

View Crossmark data 


\title{
Servants of a 'sinking titanic' or actors of change? Contested identities of social workers in Sweden
}

\section{Passiva tjänare av 'ett sjunkande skepp' eller förändringsaktörer? Ifrågasatta identiteter hos socialarbetare i Sverige}

\author{
Jessica H. Jönsson \\ Department of Social work, Mid Sweden University, Östersund, Sweden
}

\begin{abstract}
Historically, social workers have been an integral part of a well-developed welfare state in Sweden. However, due to the neoliberal changes, which have seen the weakening of the support system for vulnerable groups and individuals, the traditional 'solidary role' of social workers has rapidly altered. This has created uncertainty and dilemmas for the identification of many social workers, who still perceive themselves as promoters of 'welfare of the people'. This article dwells, therefore, on neoliberal transformations and the changing professional identity of practitioners. The study is based on a comprehensive empirical work of interviews with social workers. The results show a growing and widespread unease with new professional roles and functions of social workers as bureaucrats within a neoliberalised organisation of public social work. Some social workers still try to find creative and new ways of working in solidarity, while others, although critical, see adjustment to the new organisational frames as a way to continue their work. It is argued that social workers are not passive actors in the process of neoliberalisation of public social work in Sweden but could actively take different stances and choose their own identifications, in order to maintain the solidary role of social workers.
\end{abstract}

\begin{abstract}
ABSTRAKT
Historiskt sett har svenska socialarbetare varit en integrerad del av en välutvecklad välfärdsstat. Men på grund av de nyliberala förändringar som har inneburit en försvagning av välfärdsstaten och dess stödsystem för utsatta grupper och individer, har socialarbetares traditionella 'solidariska roll' snabbt förändrats. Detta har skapat rollkonflikter och flera dilemman för många socialarbetare som fortfarande uppfattar och identifierar sig som en profession som främjar välfärd och solidaritet. Föreliggande artikel ämnar att undersöka hur de senaste decenniernas nyliberala förändringar har påverkat socialarbetares professionella identitet i Sverige. Studien bygger på ett omfattande empiriskt material bestående av intervjuer med socialarbetare verksamma inom den kommunala sektorn. Studiens resultat visar på en växande och utbredd oro hos socialarbetare för deras nya professionella roller och funktioner som byråkrater $\mathrm{i}$ en nyliberaliserad organisation i offentligt socialt arbete snarare än välfärdsagenter.
\end{abstract}

\section{KEYWORDS}

Neoliberalism; professional identity; social work; symbolic violence; Sweden

\section{NYKELORD}

Nyliberalism; professionell identitet; socialt arbete; symboliskt våld; Sverige

CONTACT Jessica H. Jönsson jessicah.jonsson@miun.se E Department of Social work, Mid Sweden University, Östersund SE83125 , Sweden

(c) 2018 The Author(s). Published by Informa UK Limited, trading as Taylor \& Francis Group

This is an Open Access article distributed under the terms of the Creative Commons Attribution-NonCommercial-NoDerivatives License (http:// creativecommons.org/licenses/by-nc-nd/4.0/), which permits non-commercial re-use, distribution, and reproduction in any medium, provided the original work is properly cited, and is not altered, transformed, or built upon in any way. 
Resultatet visar också att socialarbetarna reagerar på olika sätt mot sina nya nyliberala professionella roller och funktioner. En del försöker hitta kreativa och nya sätt att arbeta i solidaritet, medans andra, kritiska attityder tilltrots, ser en anpassning till nya organisatoriska ramar som ett sätt att fortsätta sitt jobb. Artikelförfattaren menar att socialarbetare inte behöver vara passiva aktörer i nyliberaliseringsprocessen av det offentliga socialt arbetet i Sverige, utan kan vara aktiva aktörer i att motverka nyliberala förändringarna inom professionen och inta solidariska arbetssätt och identiteter.

\section{Introduction: on shaky ground}

'Like a sinking Titanic'; that is how social workers describe the current state of public social services in Sweden (Sveriges Television, 4 February 2015). The similarity between the image of Titanic as an 'unsinkable ship' and the image of the Swedish welfare state as one of the world's strongest and most lasting institutions is striking. In each case, the most vulnerable groups pay the price of its failures. The image of Sweden is much stronger than the reality of its welfare state, which has undergone three decades of neoliberalisation and marketisation with substantial impact on social policy, social work education and practices (Kamali \& Jönsson, 2018). Neoliberalisation as a socioeconomic doctrine believes in the ideological dominance of the necessity of a global market with the minimum control of the nation state. As Harvey (2005) puts it, neoliberalism is a theory of political economic practices that proposes that human wellbeing can best be advanced by liberating individual entrepreneurial freedom characterised by strong private property rights, free markets and free trade. The role of the state is thus to create and preserve an institutional framework appropriate to such practices. One of the consequences of neoliberalism is, according to Bourdieu (1998), the dominance of individualism and the destruction of collectivism. This leads, according to Bauman (2001), to the loss of state-centred institutions and a moral blindness attached to uncontrolled market competition.

OECD reports show that Sweden is among those countries with them highest adjustment of their societies to neoliberal transformations (OECD, 2011, 2013, 2016) (Figure 1).

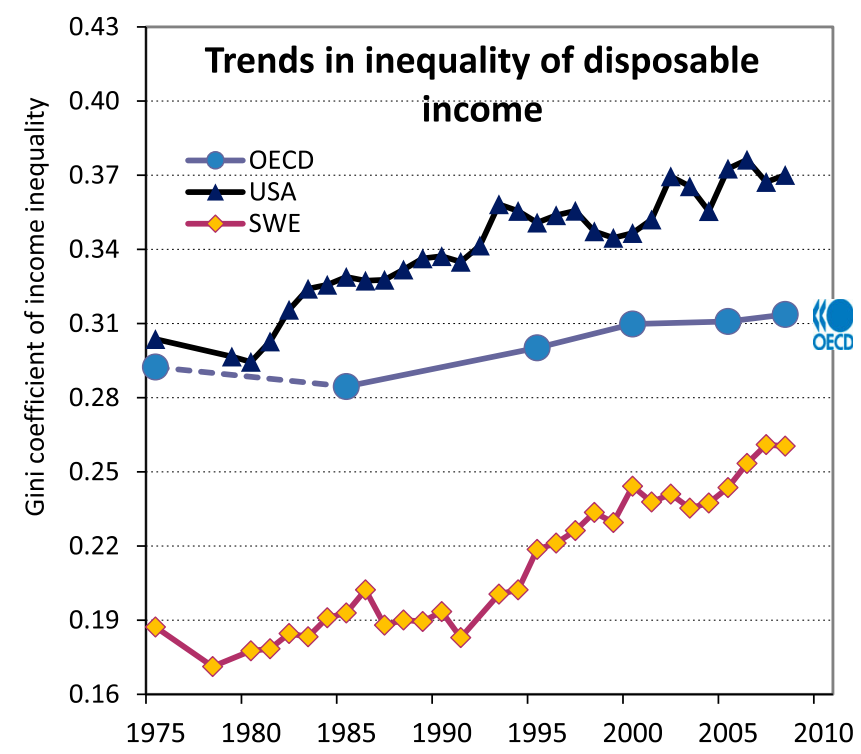

Figure 1. Trends in inequality of disposable income. Source: OECD Social Expenditures database. www.oecd.org/social/ expenditure.htm. 
The reconstruction of the Swedish welfare system because of the neoliberalisation of the country is challenging the established image of Sweden as a bastion of equality, equity and social cohesion.

The neoliberal reorganisation and a 'social work in crisis' in Sweden have led to a situation in which municipal authorities and social workers are not able to guarantee the rights and entitlements of people (Jönsson, 2015). The blame is often put on social workers who have the 'street-level' contact with people in need of the welfare state's interventions. This is a result of a political and media cover up of what really is happening with a welfare state in retreat from its traditional obligations. Social workers are working hard in difficult times with scarce resources to help people in need and are in a constant struggle within neoliberalised organisation and routines.

However, neoliberal changes of the Swedish welfare state have not passed without resistance. Critical voices are growing in a country where critics of the cooperation between the state and the market have traditionally not been strong. Although there have been critics against 'paternalistic features' of the welfare state during earlier periods, this critique was not against neoliberalisation of the Swedish welfare state. The critical voices of today from academics, educators and practitioners focus more explicitly on the neoliberalisation of Swedish society and the retreat of the welfare state. The Swedish state is today highly criticised for not taking its traditional responsibilities (existing even during the 1970s and 1980s) for the welfare of people. Such voices are increasingly challenging the deterioration of people's living conditions because of the rapid neoliberalisation of Swedish society. Social workers are protesting against worsening of their working conditions, managerial legal and administrative frames replacing the traditional and solidary basis of social work, limited support to people in need, individualisation and fragmentation of social work instead of holistic approaches and growing stress and burnout among social workers. Protests have been organised and carried out by critical networks among social work practitioners, students, and service users in Sweden e.g. by KAOSA, Kritiska Organiserade Socialarbetare (Critical Organised Social Workers), SFSA, Socialarbetare för social aktion (Social Worker for Social Action) and NBT, Nu bryter vi tystnaden (Now We break the Silence), and numerous demonstrations through social work unions and social workers organised in different parts of the country. Although there is evidence in previous literature that social workers may respond differently to transformations in their organisations, we know less about responses related specifically to the neoliberal political landscape of Swedish welfare and social work, as will be explored in this article.

\section{The study}

This study explores social workers' responses to recent decades' neoliberal transformations of the Swedish welfare state and social work. The following questions have guided the study: How has the recent political, social and organisational transformations influenced the self-image of social workers? How have such transformations influenced social workers' professional identification? How do social workers respond to neoliberal changes in and limitations to their professional activities?

Since the main objective of the study is to capture social workers' understanding of their professional roles and functions within neoliberalised frames of social work organisations, this study has a qualitative approach. The sample is composed of social workers engaged in different areas of public social work, such as child and family welfare, addiction care, economic support and social work with migrants and asylum seekers. The author have conducted interviews with 15 social workers (11 women and 4 men) during 2016-2017 in the three Swedish cities of Gothenburg, Malmö and Stockholm in which urban social problems such as marginalisation have rather dramatically increased during the last three decades of neoliberalisation of Swedish society. Three social workers have more than 20 years of experience. Eight of the social workers have between 5-10 years of experience and four of them have newly stepped into the profession with less than 5 years of experience. The 'voices from within', which are about social workers' experiences of 'being a social worker' in a neoliberal organisational landscape, have been analysed using QCA qualitative content analysis (Graneheim \& Lundman, 2004). The use of QCA aimed at interpreting 
variations through identifying differences and similarities in content, expressed as categories and themes at various levels of abstraction. By using this method of analysis, it was possible to identify relevant categories and themes and to provide a comprehensive understanding of its manifest and latent contents and messages in the frame of relevant critical social theoretical perspectives. Although QCA is inductive, it does not need to exclude deductive reasoning (Patton, 2002). Using theory and previous studies was useful in the process of data analysis (Berg, 2001), i.e. initial coding starts with theory and relevant research findings (Hsieh \& Shannon, 2005).

The first part of the article explores the neoliberal political context of social welfare and social work in Sweden. The next part introduces the theoretical concepts of 'symbolic violence' and 'governmentality' used in the article to analyse the way social workers have been influenced by recent neoliberal transformations. The following part of the article provides illustrations of difficulties faced by social workers in their daily activities, difficulties that create ethical dilemmas and impact their professional identities and aspirations, but also evoke resistance and protests among social workers. The focus of the final part of the article is on the responsibility of social work as a profession and social workers as individuals to resist neoliberal methods and managerial techniques that reduce social workers to neoliberal administrators, which helps to reproduce inequalities and injustices in society.

\section{Neoliberal transformation of the Swedish welfare and social work}

As one of the most significant socioeconomic, political, ideological and cultural changes to the world during recent times, neoliberalism 'transmogrifies every human domain, along with human subjectivity itself, and all spheres of existence are framed and measured by economic terms and metrics, even when those spheres are not directly monetised' (Brown, 2015).

One of the major reasons behind the 'neoliberal turn' can be found in the shift in hegemonic political and economic ideology from socialism to neoliberalism, the latter privileging the private sector, which also has brought with it a 'welfare blindness', causing the general majority to be relatively uncritical of the political leaders and authorities whose traditional duties have been to provide welfare to the people (Vejlby, 2011). The weakening of political opposition to neoliberal ideology has created some kind of general 'acceptance' of neoliberal reforms as necessary for the 'wellbeing of the people'. Such a relative acceptance is important for a neoliberal governmentality to exist (Foucault, 1979/2008). This means a neoliberal technique of governance by which people are convinced that the superiority of the global market is the only alternative. Notwithstanding growing protests against neoliberal reforms and marketisation of the welfare state, the political message is almost the same: 'there is no alternative' to neoliberalism, in Margaret Thatcher's words. Neoliberalisation conducted by both the right wing and social democratic governments in Sweden is almost neutralised and de-politicised. As a result, the commoditisation of social welfare services as well as the adoption of private sector management philosophies and tools have 'colonised and fashioned the design, provision and implementation of social welfare policy and structures' (Spolander, Engelbrecht, \& Sansfacon, 2016).

The welfare state reforms in Sweden have created a 'welfare market' in which private organisations and individuals are able to obtain considerable economic benefits from public expenditures. Many traditional political and ideological advocates of the welfare state, such as social democrats, who are now influenced by the hegemonic neoliberal ideology, are re-defining the domains of the welfare state and the role of politics and social policy in providing welfare to people.

Given that neoliberalism is about to 'make governance cheaper' and limit the scope of the government intervention of the market, it is expected that the financial burden of the welfare state should be less in a time of a neoliberal reorganisation of the welfare state. However, this is not the case in the face of evidence. Studies and statistical reports show that notwithstanding neoliberal reforms and marketisation of welfare services, the public costs of the welfare state have increased (OECD, 2016). Paradoxically, the increase of public expenditures has not been targeting people in need of such services. This is mainly due to the new profit-hunting actors in the 'welfare market', which 
receive a large part of social expenditures as the mediators of services (Jönsson, 2015; Jönsson \& Kojan, 2017).

Such transformations have dramatically changed the way social work has traditionally been organised and practised, as well as the way social problems are defined and dealt with, including social workers professional identities (Espvall, 2018; Lauri, 2016; Tham, 2018). New techniques, such as New Public Management (NPM) and evidence-based practice (EBP), have been created to simplify and standardise responses to individuals' and families' social problems in line with this reorganisation of the welfare state (Petersén \& Olsson, 2015; Ponnert \& Svensson, 2016). Social workers have historically been an integral part of a well-developed welfare state in Sweden. However, the 'solidary role' of social workers has rapidly altered due to the neoliberal changes, which has weakened the social support system. This has created 'identity crises' for many social workers who still perceive themselves as promoters of 'welfare of the people'. The realm of social workers' influence on the fulfilment of their mandate for the social dimension of public life is curtailed by neoliberal constraints (|Lorenz, 2016, 2017). Social workers feel strongly impacted by numerous constraints on their work, both at the macro-structural level of policy-making and organisational context of their work and at the microinterpersonal level (Jönsson, 2015; Lauri, 2016).

Social work in Sweden has only until recently acknowledged the limited professional possibilities for social workers to provide services, as well as the existence of serious tensions between neoliberal strategies and the professional ethics and core values of social work. As some studies have hinted, social work and social workers are increasingly detached from including and dealing with the structural and institutional aspects of social problems, with people in need of social work interventions 'becoming' responsible for their social problems (Dahlstedt \& Lozic, 2017; Jönsson, 2013; Sernhede, 2018). This forces social workers to continuously negotiate the boundaries of their professional responsibilities in relation to the core values of the profession. Neoliberal imperatives and requirements create many dilemmas for social workers, who are concerned with addressing the structural conditions of social problems and with collective empowerment (Jönsson, 2018). Indeed, overemphasising the individual responsibility of people in need of social work interventions in respect to their social problems runs the risk of seeing social workers operate in the capacity of 'controller' (Cuadra Björngren \& Staaf, 2014; Skjefstad, Kiik, \& Sandoval, 2018) rather than as an agent of change.

Although such responses are uneven and interchangeable, they are strong signs of a profession in transition targeted by growing neoliberal political and organisational changes. The vulnerable position of social workers and the space that the neoliberal reorganisation of social work has created for those employed within public social work in Sweden creates a confusing position for social workers.

\section{The neoliberal governance of social work}

This study uses the theoretical concepts of 'symbolic violence' (Bourdieu) and 'governmentality' (Foucault) to analyse the way social workers have been influenced by recent neoliberal transformations and the changing of their professional identity. 'Governmentality', in Foucault's theoretical standpoint, corresponds well with Bourdieu's concept of 'symbolic violence' for studying the formation of power and knowledge governing society (see also Kamali, 2015). It provides a theoretical framework for analysing technologies of self as they intersect with technologies of domination. By technologies of self I mean here the combination of 'taking care of oneself' and de-politicisation of one's actions in order to protect oneself from being subjected to punishment by political and bureaucratic organisations. In the neoliberal organisation of social work, a combination of technologies of self and technologies of domination helps to reproduce inequalities. Such theoretical perspectives are necessary to explore unequal practices in society and the role of social work for promoting social justice and social change (see also Donovan, Rose, \& Connolly, 2017; Garrett, 2007a, 2007b; Hewitt, 1983; Kamali, 2015; Lauri, 2016). It can be said that disciplinisation, based on power structures in society, makes the reproduction of privileged positions and structures possible. Reproduction of hierarchical positions 
and power structures in society is not only based on physical violence but also on the 'soft means of domination', i.e. 'symbolic violence' (Bourdieu, 1991, p. 190). Symbolic violence makes the mechanisms of domination possible, since every domination includes some degree of acceptance (Foucault, 1977, 1982). As Bourdieu $(1984,1991)$ puts it, human actions take place in different fields and each field has its own 'rules of games' and 'dispositions', which force individuals to adjust their actions to the field's manifest and latent rules and routines. Individuals who engage in a specific field are struggling over desirable resources and should respect and reproduce the dispositions of the field in order to guarantee obtaining privileges attached to the domination of privileged groups in society.

Neoliberalism influences more or less every field of human action and forces many to adjust themselves to neoliberal conditions. Bourdieu (1998) argued that neoliberalism involves the dominance of individualism and the destruction of collectivism. This has been one of the consequences of the increasing ideological domination of the necessity of a global market with the minimum control of the nation state. Likewise, Foucault argued that what makes states truly neoliberal is using the market to govern, distributing services and benefits according to the market logic of efficiency, competitiveness and profitability. According to Foucault (2008, p. 131), neoliberal reforms and the restructuring of society are taking place through a complex system that he calls governmentality. Governmentality as a process of governing over people and societies not only by 'monopoly over legitimate means of violence' but also through 'convincing' people of the necessity of governance and domination. Governmentality makes people accept the legitimacy of the system as necessary. In other words, neoliberalism is largely legitimised as the only possible system of organising economy, politics and culture. Those individuals who adjust themselves to neoliberal imperatives get rewarded and those who do not can be subjected to punishment.

Social workers in Sweden are mainly working within public organisations and institutions and are a professional group highly influenced by neoliberal governmentality. Overall, the notion of 'efficiency' underpins everyday activities in public social work arenas. This creates a situation in which social workers are left with dilemmas of their professional identity as the helper and not controller and agents of efficiency. Social workers are forced to react to such new working conditions in their professional practices. One such challenge is the question of identification as social workers. Traditionally, many social workers have identified themselves as solidary human beings and the workers of a 'good state' with strong welfare obligations towards people. However, in a time when the state is retreating from its traditional role as the champion of people's welfare, it is getting harder for public social workers to identify themselves as a member of a solidary profession.

\section{Result and analysis: voices from within}

In this section, social workers' experiences of working in, and responding to, the increasing neoliberal organisation of public social work is presented and analysed.

\section{Managerial professional social workers}

Overall, there is a common understanding among social workers participating in this study that recent political, social and organisational (neoliberal) reforms of the last decades have affected important aspects of social work. Such changes are expressed in the growing demand for Evidence Based Practice (EBP) , new technologies for 'simplifying' and standardising social problems and their roots, by stressing efficiency, individual responsibility and standardisation of the provision of social services. Social workers tell me about procedures akin to rationalisation and standardisation as the consequences of neoliberal reorganisation of welfare state, which in different ways have affected social work practice. 'Elena', an experienced social worker within the field of addiction care, states:

We have standardised the way we solve complex problems by always 'choosing' the same measures, because it its cheap and does not cost much. I am indeed educated, competent and experienced enough to do professional assessments but it seems not what the organisation want me to do. 
Further, the emphasis on 'efficiency' and on 'budget management skills' has led social workers away from what many social workers consider as the heart of social work, namely meeting the needs of people in their social realities formed by broader structural approaches in social work. Sitting behind a desk being a paper-pusher/secretary is not only extremely time consuming but also hinders social workers from meeting peoples' needs in their everyday lives, as many uttered. Interviewee 'Josephine', working with child and family care and with several years of professional experience, tells how this affects her work:

I feel like a programmed machine. I mean, anybody could do what we are doing, there is no need for professional knowledge. This is not what I have been educated for. Everything is so standardised. I have left my jobs several times and found another, believing that it would be better somewhere else and I could work differently, but it was not the case, it is the same everywhere.

Or as another social work colleague, working in the same area with only a few years of professional experience, 'Emelie' puts it:

I spend almost all of my time by the computer, making calls, writing documents, and so on. Following manuals, it is a hell to fill out forms and it take so much of my time and steal time from to many other things that I as a social worker should do. I would rather meet my clients face-to-face.

This technological basis for practice, represented by the 'electronic turn' in social work (Garrett, 2005), is changing the functions and mandates of social workers. Within new organisational conditions, the work is increasingly being ordered and structured by neoliberal policy makers far removed from the day-to-day encounters that social workers have with service users. The new way of standardisation of social work, which often is legitimated as making social work more effective, empties social work practice from its human qualities. Neoliberal governmentality leaves no space for social workers' autonomous evaluations of their work and consequences of their interventions. They are increasingly disciplined in new working conditions, which really do not need educated and creative social workers. Respondents to this study acknowledge that they do not have the time for comprehensive social work but take rapid and technical decisions for short-term interventions. 'We just scratch on the surface', says 'Lila', one of the interviewed social workers. She is realising that their documentation of people's social problems, and their assessments on the same, are rather simplified and watered-down:

There is basically no time for detailed assessment writing, my colleagues have piles of papers and notes that have not been registered for many months ... We just 'sum things up', I do not think the content of the assessments make any sense to (who it concerns) our 'clients' ...

As argued here, this violates even Swedish laws, which regulate social workers' actions. Practitioners argue that in many cases they see the needs and are aware of the rights of people as well as of ethical issues in their work, but realise that they are not able to do much because of their workload and shortage of time. 'Lydia', at a child and family section, argues:

In order to do the most urgent and short time interventions, serious and important matters and cases are ignored. This leads often to the situation that we get the problems of the families back again. I don't see the point ...

There is an obvious un-ethical tendency in neoliberalised social work in Sweden. Many social workers experience that they have to accept such a strategic/rationalised documentary tendency in social work because of a top-down power structure in public organisations of social work. Not adjusting themselves to such neoliberal and managerial imperatives will not be in the individual interests of social workers, i.e. in Foucault's words 'taking care of the self'. They can be sanctioned negatively or punished, in Bourdieu's (1991) word. As 'Malin', by referring to her social work with economic support, says:

One is always controlled. My chief is going through my documents, decisions and what I write about my clients. I have her control in my mind when writing my assessments and make decisions. I feel that my education and what I have learned is not recognised and valid here, I have simply to accept what the chief wants me to do. Otherwise, I risk my job. 
Or, as 'Samuel', working with social and economic support to people in marginalised areas, says, 'accepting what the organisation and those in power - the leadership - want is emancipatory, because then you do not need to have any confrontation with them'. Such an acceptance is part of the domination, as Foucault (2008) argued. Accepting the 'rules of games' makes working easier for social workers, since the domination is not confronted with resistance and objections. Neoliberal policies and 'NPM-ethics' are characterised by stressing the importance of measurable outputs, targets and cost effectiveness in the provision of public services. However, the narratives of the social workers rather offer a critique of such and emphasise the importance of reclaiming professional ethics for social work - ethics of social justice (Banks, 2011).

Social workers act in accordance with performance-based models of NPM and private-sector-like organisational models of work based on 'tighter' management control of the labour process, ongoing intensification of work, reduction of costs, increased standardisation, reduction of waste, the use of just-in-time deliverables and close monitoring of all aspects of work (Baines, 2004). In some of the municipal public social work organisations, they have introduced 'lean thinking' (lean manufacturing or lean production) for the social services' new systems. Lean work highlights the general lack of funding in the social services sector, which severely reduces the capacity to provide quality social services and effectively removes the possibility for social workers to provide holistic social services.

For example, social workers' narratives suggest that the important goal of empowerment is not realised. Rather, the findings show that participatory empowerment social work is hard to achieve. Social workers describe that their expanded workloads imply that work tends to be conducted at the last minute with little or no room for assessing empowering processes. The current neoliberal model of social work needs only 'uncritical servants' who accept and work in accordance with what is defined by the leading section of the organisation as desirable social work.

The recent emphasis on 'modernisation' and 'professionalisation' in social work in Sweden has been an effort to replace critical analysis and perspectives necessary for understanding and working with social problems. An uncritical celebration of new 'theory-less' methods and manuals in social work practice has also meant a move away from traditionally strong system of preventive social work in Sweden. As social worker, 'Jenny', puts it:

Preventive work, who has time for that? We have no time to work with long-term goals, to find real solution to people's problems. We work merely with short-term interventions, like hospital emergency centres, or like firefighters putting out fires - the most urgent actions, not more.

This also affects social workers' relations to people whom they want to help by establishing a trustful relation.

\section{Changing the solidary role of social workers}

Many social workers are aware of consequences of the neoliberal reorganisation of the Swedish public social work. Social worker 'Kathrine' means that the system is creating frustration, disappointment and anger among service users, which in turn leads to distrustful relations between social workers and people they intend to help within the frames of public social work organisations.

Interviewee 'Gunhild', with more than twenty years of professional experience in social work related to addiction, homelessness and prostitution, tells about how individual responsibility for welfare is built into systems of reward and punishment within social work interventions and how this influences the solidary role of social workers. She says:

Those who accept the new way of the organisation of our work, which is decided over our heads, are no problems. On the contrary, they can be rewarded by being entitled to participate in new courses and short-term education that can help them up in the organisation. This is not the case for other of us, treated as 'deviants'. Who knows, we can even be forced to leave our jobs.

Referring to social work with migrants and asylum seekers, another interviewee, 'Victor', who is critical of being a controller and 'not a solidary worker' in his words, says: 
The chief has said to my colleagues that those who do not like their work and the organisation they are working in should leave, find another job. She has signalled that persons like me are not going to do any career in this organisation, and I know that she is absolutely right.

The quotes above can be understood by the theoretical perspective of symbolic violence (Bourdieu, $1984,1991)$. Those who accept and adjust themselves to the NPM models of social work are rewarded and those who do not are punished in different ways.

Another social worker, 'Eva', is frustrated about the contradictory situation created for her. She sees no space for working in accordance with her education and professional intentions for helping people in need of her competency and skills. She says:

I feel like a 'bad social worker', I am educated to help people but I can't do that. I do not have the possibilities or time to do so. I feel frustrated and incomplete. The level of social work today has fallen dramatically. I think that you cannot be the social worker you wanted to be when you choose the profession.

Another illustration of the impact of neoliberalisation on social work and its demoralising effects on the professional identity of social workers is that the influence of neoliberal ideologies and policies has seen stress placed on the 'responsibilisation' of both service users and professional social workers. This responsibilisation forces social workers to continuously negotiate the boundaries of their professional responsibilities in relation to the core values of the profession. Such neoliberal imperatives and requirements create many dilemmas for social workers. One example is the fact that policymakers define and find solutions to social problems without using social workers' professional knowledge and competency. As expressed by social worker 'Lila':

The new forms of organising and steering social work activities show that politicians and those in leading positions do not trust our professional ability and skills. I have educated myself several years and have many years of experience in social work practice, no politicians with not enough knowledge of social work should tell me what I should do or not should do. The most important thing for them is the budget balance and economic calculations. They do not give a damn about our competency or people's social problems.

Some social workers put the blame for their problematic working situation on themselves. 'Kathrine', an experienced social worker, is reflecting back on her recent years in social work with children 'at risk' and says:

If I had a better managerial capacity, I maybe would be able to work more effectively, and at the same time I would be able to be successful in helping clients?

This can be understood as a way to accept the dominance of neoliberal organisational domination by trying to change the focus from the problems created by the neoliberal organisational models, such as NPM, to the individual social worker's bureaucratic and managerial abilities. The acceptance and accomplishment to neoliberalism is important for the reproduction of the dominance (Foucault, 2008) and the reward (Bourdieu, 1991) from the leading section of the organisation.

The interviews with social workers grasp the contested relationships and roles within the Swedish social welfare as a system traditionally created to maintain the well-being of individuals. Social workers are forced to adjust themselves to NPM imperatives including adjustment to discontinuities and disruptions in their contacts and work with service users. As a result, service users are forced to frequently change their social workers and meet new persons. This becomes more problematic when social workers' real time for face-to-face meeting with service users is increasingly shrinking. 'Kathrine' says:

Sometimes, my clients apologise for 'taking my time' ... even if it is me who are supposed to help them. I am here for them, it is horrible that it has gone so far...

Such working conditions leave social workers with the choice of either adapting to such conditions or resisting them in different ways. In many ways, the difficulties for social workers are based on what has traditionally been the solidary identity of social workers. The rapid neoliberal transformations of 
the public social work provoke different reactions from social workers, who may adopt a variety of positions towards such changes in their daily work.

\section{Critical stands and acts of change}

The voices from the 'sinking ship' of the Swedish public social work demonstrate that the ways in which social workers have responded to such rapid changes have not been homogenous. Because of fear of punishment, many accept their 'places in the hierarchy' and the imperatives from the neoliberal organisations' leadership. They demonstrate little or no resistance at all in order to be an accepted part of the new neoliberal field of social work. Meanwhile, others have responded by adopting a more practical stance that encompasses explicit critical perspectives and activities.

However, irrespective of social workers' individual choices of alternatives and strategies towards neoliberal changes and leadership, social workers participated in this study utter severe concerns about their professional identities. All social workers mean that they have chosen the profession of social work for its solidarity content and not for a managerial control of people in need of social work interventions. They are critical of neoliberal policies and practices, which have resulted in growing rationalisation, standardisation and individualisation of social problems and social work practices in a profession, which earlier included structural and holistic perspectives in working with marginalised and vulnerable people. In outlining resistance to and struggle against such neoliberal politics, social workers are aware of the need for collective social action and organisation. Social worker, 'Malin' urges that:

Organise yourself for change. Alone, you are not strong, there are already so many who tried to fight the situation alone and I was one of them. This is a costly way to go, you get sick and have to leave.

As a profession engaging in upholding human rights and social justice and committed to eliminate oppression, some social workers argue for the engagement of social workers in protest movements against, and resistance to, the neoliberal policies, marginalising mechanisms, welfare nationalism and racism that influence many people's life chances. They mean that many of such structural and institutional aspects of oppression are sacrificed in the process of neoliberalisation of social work practice. Some respondents provide examples of such social work action networks, e.g. social workers go together with local non-governmental organisations to support and find solutions to undocumented immigrants by taking creative and sometimes 'illegal' actions. Some social workers say that they are participating in critical networks among social work practitioners, students and service users, such as the network Social Workers for Social Action, (SFSA). As 'Walter' puts it:

The aim of our network is to create better opportunities for social workers, We are trying to create alternative ways of working and show to social workers that another social work is possible which is not limited to just follow what the politicians want us to do and force us to just follow laws and rules. This means that we have to follow our professional ethics and knowledge in order to help people in need of our services even if it goes against laws, rules and organisational routines. It is about solidarity and compassion.

Through SFSA, social workers arrange conferences, seminars, networking days and different social activities bringing together politicians, academics, social workers and service users to critically discuss the politics of neoliberalism and to participate in the public debate to resist. In an article in Dagens Arena (31 January 2011) Socialarbetare för Social Aktion (SFSA) social work practitioners and social work students together stress the importance of informed social work educators for the development of critical knowledge in social work education, which will prepare future social workers for working in an environment in which neoliberalism creates complex social problems. Participating in critical networks helps social workers, as they put it, to 'regain the real role and function of being a social worker'. As 'Fatima', a child welfare social worker puts it:

We have to do something, we cannot passively accept what they force us to be, passive followers of orders and documents written by those who do not know anything about our realities; administrators who are occupied with efficiency, papers, rules, laws, and end-oriented calculations. This is about human beings' lives. I participate in 
SFSA because of the solidary basis of their activities, otherwise I cannot be at ease with my role as a social worker. I have chosen social work for helping people and not for having just a job.

This illustrates Michel Foucault's famous argument, i.e. 'where there is power, there is resistance' (1990).

\section{Concluding remarks}

In the current neoliberal organisational landscape and the hegemony of the political neoliberal ideology, which even have highly influenced social democratic parties and groups in Sweden, social workers seems to be in an state of uncertainty influenced by paradoxes and dilemmas of role conflicts and identification. Although some social workers are adjusting themselves to neoliberal models based on their need of having a job or accepting neoliberal reorganisation of the Swedish welfare state, many others are critical and try to resist neoliberalisation and the retreat of the welfare state.

Resistance to neoliberalisation of public social work in Sweden is a part of an active identification of many social workers to their role of solidarity with marginalised and vulnerable groups. Many consider themselves agents of helping people in need and improving unprivileged groups' living conditions, being the agents of change and not the 'servants of a sinking Titanic'. This requires taking a radical 'political stance' in social work (McKendrick \& Webb, 2014), to resist the politics of neoliberalism, which reduce social workers to be neoliberal administrators and help to reproduce inequalities and injustices in society. The identity crisis of many social workers is dependent on such a situation, created by the neoliberal and managerial organisation of social work. However, social worker are not passive actors in this process but could actively take different stances and choose their own identifications. In order to maintain the solidary identity of social workers, they can find creative ways of resisting neoliberal changes and, together with movements against neoliberalism, help to hinder the sinking of the welfare ship.

\section{Disclosure statement}

No potential conflict of interest was reported by the author.

\section{Notes on contributor}

Jessica H. Jönsson (PhD) is a senior lecturer and associate professor at the Department of Social Work, Mid Sweden University, Sweden. Her research area concerns social work as a globalised and socio-political field facing increasing theoretical and practical challenges caused by neoliberal socioeconomic, political and cultural transformations. She has studied the impact of neoliberal globalisation and its consequences for social work, such as forced migration, global social problems, welfare nationalism and national reorganisation of social work, including its education and practices.

\section{References}

Baines, D. (2004). Caring for nothing: Work organizations and unwaged labour in social services. Work, Employment and Society, 18(2), 267-295.

Banks, S. (2011). Ethics in an age of austerity: Social work and the evolving new public management. Journal of Social Intervention: Theory and Practice, 20(2), 5-23.

Bauman, Z. (2001). The individualized society. Cambridge: Polity Press.

Berg, B. L. (2001). Qualitative research methods for the social sciences. Boston, MA: Allyn \& Bacon.

Bourdieu, P. (1984). Distinction: A social critique of the judgement of tastes. New York, NY: Routledge \& Kegan Paul.

Bourdieu, P. (1991). Language and symbolic power. Cambridge, MA: Harvard University Press.

Bourdieu, P. (1998). The essence of neoliberalism: What is neoliberalism? A programme for destroying collective structures which may impede the pure market logic. LE MONDE diplomatique [online]. Retrieved from http:// mondediplo.com/1998/12/08bourdieu

Brown, W. (2015). Undoing the demos: Neoliberalism's stealth revolution. New York, NY: Zone Books.

Cuadra Björngren, C., \& Staaf, A. (2014). Public Social Services' encounters with irregular migrants in Sweden: Amid values of social work and control of migration. European Journal of Social Work, 17(1), 88-103. 
Dahlstedt, M., \& Lozic, V. (2017). Managing urban unrest: Problematising juvenile delinquency in multi-ethnic Sweden. Critical and Radical Social Work, 5(2), 207-222.

Donovan, J., Rose, D., \& Connolly, M. (2017). A crisis of identity: Social work theorising at a time of change. British Journal of Social Work. Advance online publication. doi:10.1093/bjsw/bcw180.

Espvall, M. (2018). Professional strategies and neoliberal challenges in Swedish social work practice. In M. Kamali \& J. H. Jönsson (Eds.), Neoliberalism, Nordic welfare states and social work: Current and future challenges (pp. 148-158). London: Routledge.

Foucault, M. (1976/1990). The history of sexuality, volume 1: An introduction. New York, NY: Vintage Books.

Foucault, M. (1977). Discipline and punish: The birth of the prison. London: Allen Lane.

Foucault, M. (1979/2008). The birth of biopolitics. Lectures at the Collège de France, 1978-1979. New York, NY: Palgrave Macmillan.

Foucault, M. (1982). The subject and the power. In H. Dreyfus \& P. Rabinow (Eds.), Michel Foucault: Beyond structuralism and hermeneutics (pp. 208-226). Brighton: Harvester.

Garrett, P. M. (2005). Social work's 'electronic turn': Notes on the deployment of information and communication technologies in social work with children and families. Critical Social Policy, 25(4), 529-553.

Garrett, P. M. (2007a). Making social work more Bourdieusian: Why the social professions should critically engage with the work of Pierre Bourdieu. European Journal of Social Work, 10(2), 225-243.

Garrett, P. M. (2007b). The relevance of Bourdieu for social work: A reflection on obstacles and omissions. Journal of Social Work, 7(3), 355-379.

Graneheim, U. H., \& Lundman, B. (2004). Qualitative content analysis in nursing research: Concepts, procedures and measures to achieve trustworthiness. Nurse Education Today, 24(2), 105-112.

Harvey, D. (2005). A brief history of neoliberalism. Oxford: Oxford University Press.

Hewitt, M. (1983). Bio-politics and social policy: Foucault's account of welfare. Theory, Culture and Society, 2(1), 67-84.

Hsieh, H. F., \& Shannon, S. E. (2005). Three approaches to qualitative content analysis. Qualitative Health Research, 15(9), 1277-1288.

Jönsson, J. H. (2013). Social work beyond cultural otherisation. Nordic Social Work Research, 3(2), $159-167$.

Jönsson, J. H. (2014). Local reactions to global problems: Undocumented immigrants and social work. British Journal of Social Work, 44(1), i35-i52.

Jönsson, J. H. (2015). The contested field of social work in a retreating welfare state: The case of Sweden. Critical and Radical Social Work, 3(3), 357-374.

Jönsson, J. H. (2018). Välfärdsstatens försvagning, ökade sociala problem och social mobilisering [A retreating welfare state, increasing social problems and social mobilisation]. In S. Sjöberg \& P. Turunen (Eds.), Samhällsarbete Aktörer, arenor och perspektiv [Community work - actors, arenas and perspectives] (pp. 237-254). Lund: Studentlitteratur.

Jönsson, J. H., \& Kojan, B. H. (2017). Social justice beyond neoliberal welfare nationalism: Challenges of increasing immigration to Sweden and Norway. Critical and Radical Social Work, 5(3), 301-317.

Kamali, M. (2015). War, violence and social justice: Theories for social work. London: Routledge.

Kamali, M., \& Jönsson, J. H. (2018). Neoliberalism, Nordic welfare states and social work: Current and future challenges. London: Routledge.

Lauri, M. (2016). Narratives of governing: Rationalization, responsibility and resistance in social work (doctoral dissertation). Retrieved from http://umu.diva-portal.org/smash/get/diva2:923799/FULLTEXT01.pdf

Lorenz, W. (2016). Rediscovering the social question. European Journal of Social Work, 19(1), 4-17.

Lorenz, W. (2017). European policy developments and their impact on social work. European Journal of Social Work, 20(1), $17-28$.

McKendrick, D., \& Webb, S. (2014). Taking a political stance in social work. Critical and Radical Social Work, 2(3), 357-369.

OECD (2011). Divided we stand: Why inequality keeps rising. OECD Publishing. doi:10.1787/9789264119536-en

OECD (2013). Increasing inequalities between 1980s to 2012. OECD Publishing. Retrieved from http://www.oecd.org/els/ soc/49499779.pdf

OECD (2016). OECD social expenditures database. OECD Publishing. Retrieved from http://www.oecd.org/social/ expenditure.htm

Patton, M. Q. (2002). Qualitative research and evaluation methods. Thousand Oaks, CA: Sage.

Petersén, A. C., \& Olsson, J. I. (2015). Calling evidence-based practice into question: Acknowledging phronetic knowledge in social work. British Journal of Social Work, 45(5), 1581-1597.

Ponnert, L., \& Svensson, K. (2016). Standardisation - the end of professional discretion? European Journal of Social Work, 19(3-4), 586-599.

Sernhede, O. (2018). Urban marginality, social mobilisation and youth work in the shadow of neoliberalism and segregation. In M. Kamali \& J. H. Jönsson (Eds.), Neoliberalism, Nordic welfare states and social work: Current and future challenges (pp. 238-248). London: Routledge.

Skjefstad, N. S., Kiik, R., \& Sandoval, H. (2018). The role of social workers under neoliberal ideology at the Norwegian Labour and Welfare Service (NAV). In M. Kamali \& J. H. Jönsson (Eds.), Neoliberalism, Nordic welfare states and social work: Current and future challenges (pp. 137-147). London: Routledge. 
Socialarbetare för social aktion (SFSA) [Social Workers for Social Action]. (2011, januari 31). De som inte ges utrymme finns inte! [Those not provided space do not exist] Retrieved from http://www.dagensarena.se/opinion/socialarbetare-forsocial-aktion-de-som-inte-ges-utrymme-finns-inte/

Spolander, G., Engelbrecht, L., \& Sansfacon, A. P. (2016). Social work and macro-economic neoliberalism: Beyond the social justice rhetoric. European Journal of Social Work, 19(5), 634-649.

Tham, P. (2018). A professional role in transition: Swedish child welfare social workers' descriptions of their work 2003 and 2014. The British Journal of Social Work, 449-467. doi:10.1093/bjsw/bcx016

Vejlby, S. (2011). War, xenophobia, and the death agony of the Danish social democratic welfare state. Socialism and Democracy, 25(2), 44-57. 